NBER WORKING PAPER SERIES

\title{
THE PRIVATE NET BENEFITS OF RESIDENTIAL SOLAR PV: THE ROLE OF ELECTRICITY TARIFFS, TAX INCENTIVES AND REBATES
}

\author{
Severin Borenstein \\ Working Paper 21342 \\ http://www.nber.org/papers/w21342
NATIONAL BUREAU OF ECONOMIC RESEARCH
1050 Massachusetts Avenue
Cambridge, MA 02138
July 2015

I am indebted to Karen Notsund for many conversations and valuable insights on this research. For excellent research assistance, I am grateful to Patrick Baylis and Walter Graf. For helpful comments, I also thank Joe Aldy, Susan Buller, Estelle Cantillon, Lucas Davis, Don Fullerton, Ken Gillingham, Koichiro Ito, Shayle Kann, Billy Pizer, Glenn Sheriff, Bob Weisenmiller, participants in the 2014 Toulouse School of Economics TIGER conference and the 2015 POWER conference, and seminar participants at Duke University and Resources for the Future. I thank Pacific Gas \& Electric for access to the data that made this project possible. PG\&E contributed no financial support to this study and had no editorial control over the result. The views expressed herein are those of the author and do not necessarily reflect the views of the National Bureau of Economic Research.

NBER working papers are circulated for discussion and comment purposes. They have not been peerreviewed or been subject to the review by the NBER Board of Directors that accompanies official NBER publications.

(C) 2015 by Severin Borenstein. All rights reserved. Short sections of text, not to exceed two paragraphs, may be quoted without explicit permission provided that full credit, including $\odot$ notice, is given to the source. 
The Private Net Benefits of Residential Solar PV: The Role of Electricity Tariffs, Tax Incentives and Rebates

Severin Borenstein

NBER Working Paper No. 21342

July 2015

JEL No. L94,Q42,Q52,Q58

\begin{abstract}
$\underline{\text { ABSTRACT }}$
With dramatic declines in the cost of solar PV technology over the last 5 years, the electricity industry is in the midst of discussions about whether to use this low-polluting renewable energy source in grid-scale generation or in distributed generation (DG), mostly with rooftop solar PV. California has led the growth in DG solar in the U.S. I use 2007 to early 2014 residential data from Pacific Gas \& Electric - the utility with largest number of residential solar customers in the U.S. - to examine the full range of private incentives for installing residential solar, from the direct payments and tax credits to the indirect incentives that result from the residential tariff design and the crediting of solar production under "net energy metering." I then study the income distribution of solar adopters and how that has changed over time. I find the skew to wealthy households adopting solar is still significant, but has lessened since 2011. Adoption continues to be dominated by the heaviest electricity-consuming households, probably because the steeply-tiered tariff structure greatly increases the private value of solar to such customers while reducing the incentive for consumers who are below median consumption. In fact, the financial incentive for those who adopt solar over the sample period may have been due nearly as much to California's tiered tariff structure as to the $30 \%$ federal tax credit. The California experience suggests that rate design can greatly influence the economic incentives for residential solar adoption and which customers receive those benefits.
\end{abstract}

Severin Borenstein

Haas School of Business

University of California, Berkeley

Berkeley, CA 94720-1900

and NBER

severinborenstein@berkeley.edu 


\section{Introduction}

Solar PV is at the center of a policy and vision debate over the future of electricity generation. As solar panel costs have declined precipitously over the last 5 years, a new battle has begun over the most effective way to deploy the technology, in grid-scale solar farms or in smaller scale on customer rooftops. On a direct cost basis, PV farms seem to have a substantial cost advantage, but distributed generation (DG) advocates argue that distributed capacity - whether solar, small wind, fuel cell, or electricity storage has special qualities that make it more valuable. ${ }^{2}$ New York state is in the midst of an initiative entitled "Reforming the Energy Vision" (REV) with one goal of wider deployment of distributed resources. ${ }^{3}$

About half of all U.S. residential solar PV systems are in California, which is often looked to as the model state for solar PV policies and adoption. The California Solar Initiative (CSI) - a state subsidy that ran from 2007 to 2013 - along with federal tax policies and the state's sunny climate often receive credit for the massive expansion of solar over the last decade, but there has also been recognition that high electricity rates combined with favorable net metering policies have played a significant role. Residential electricity rates in California are relatively high on average, and are designed to charge heavy electricity users much higher marginal rates than smaller consumers, using what is known as increasingblock pricing (IBP), inclining-block pricing or tiered pricing. Accordingly, for high-usage households, the incentive to install residential solar is greatly increased.

In this paper, I examine the range of incentives that have helped to promote residential solar in California. It is not difficult to account for the rebates available under the California Solar Initiative and fairly straightforward to calculate the size of the federal tax credit. However, estimating how much additional incentive comes from the tax advantage of accelerated depreciation that third-party owners can claim requires more careful modeling of the benefit. And it is more challenging to estimate the additional incentive resulting from increasing-block pricing and the net metering policies that most states, including California, have adopted. I attempt to value these incentives and examine how important their role may have been in supporting California's DG solar leadership.

I then use census data and a statistical matching procedure from Borenstein (2012a) to

2 I focus here on the private returns to installing residential solar PV. For discussion of the social value, see Baker et al. (2013) and Borenstein (2012a).

3 See http://www3.dps.ny.gov/W/PSCWeb.nsf/All/26BE8A93967E604785257CC40066B91A?OpenDocument 
estimate the income of residential customers installing PV and examine how the incentives have varied across households of different income brackets. As expected, I find that customers installing PV are disproportionately wealthy. The analysis, however, suggests that the concentration of PV adoption among the highest income brackets has been declining in the last few years. I also find that lower-income customers, who consume less on average, tend to install larger systems relative to their annual consumption. This causes the savings per kilowatt-hour $(\mathrm{kWh})$ produced to be smaller for low-income customers because their systems are, on average, displacing electricity from a lower tier of the increasing-block pricing. Surprisingly, I find no support for the assertion that third-party ownership (TPO) - contracts under which a company owns the panels on a customer's roof and either leases them to the homeowner or sells the homeowner the electricity from them - has disproportionately been utilized by low-income customers who adopt solar. Customers from the lower income brackets are estimated to be slightly less likely to make use of TPOs than wealthier customers.

For the systems installed under the California Solar Initiative, there are also data on the price paid for the system. I use these data to analyze how price varies with attributes of the buyer. Controlling for system size and year of installation, I find that smaller users and poorer households - customers who likely have a lower willingness to pay - pay lower prices for solar systems.

The analysis suggests that the average solar adopter since 2010 was likely to save money (in net present value) over the life of the system, provided electricity tariffs remain unchanged in real terms. In fact, even if the increasing-block pricing were replaced with a flat-rate tariff, I estimate that by 2013 solar prices were low enough that the average system installed produced net savings so long as net metering policies and the federal tax credit were maintained. If, however, electricity prices reflected more closely the long-run marginal cost of generating with efficient gas-fired generation - including a robust price on greenhouse gas emissions - the analysis suggests that DG solar would have a private cost disadvantage, even with continuation of the federal tax credit.

This experience of the utility with the largest number of solar PV installations in the U.S. makes clear that rate design can play a central role in establishing economic incentives for residential PV adoption. The level and structure of retail rates drive both the rate of adoption and the distribution of adoption and benefits across households of different income levels.

In section II, I introduce the public and confidential data sources used in the analysis. Section III presents the major incentives available to solar PV adopters (and their third- 
party providers) in California over the 2007 to early 2014 period I study. In section IV, I implement the estimation of customer income bracket and explain why it is likely to be an improvement over previous approaches to this question. Section V presents estimates of the private net benefits that solar adopting households received and how they varied across the income brackets. I conclude in section VI.

\section{Data Sources}

The primary data sources used in this analysis are a public dataset from the California Solar Initiative ${ }^{4}$ and confidential billing data obtained from Pacific Gas \& Electric under a non-disclosure agreement. For those systems that received rebates under the CSI, I match these data (based on the CSI application number), which then indicates a solar PV customer's consumption before and after PV installation along with detailed data on the PV installation and the census block group (CBG) of the customer. ${ }^{5}$

Unfortunately, not all new solar PV installations in PG\&E territory are in the CSI database. In 2007, many of the solar systems that interconnected were covered under earlier programs for which comparable data are not available. In 2012, the CSI rebate dropped to very low levels and then, during 2013, disappeared entirely. As a result, most recent solar adopters have not filed with the CSI and submitted the CSI data. Even in peak years, only about $80 \%$ of new systems installed by PG\&E residential customers appear in the CSI as PG\&E administered systems. ${ }^{6}$ The billing data I have indicate the date of the customer's PV system interconnection and size of their system, but no information on cost or incentives received. So, some calculations have to be adjusted to make use of the most informative data, as described below. I discuss the robustness of conclusions to alternative data screening.

As of November 2014, there were about 70,112 systems in the CSI database under PG\&E administration, of which 58,460 were completed under the Expected Performance-Based Buydown (EPBB) program that pays an upfront rebate and 1484 were under the PBI program that pays a per-kWh rebate for production in the first 5 years. I do not analyze

4 Available at http://californiasolarstatistics.ca.gov/current_data_files/

5 A CBG includes an average of about 600 houses.

6 New homes were covered under a separate program, the New Solar Homes Partnership. A small number (under 2000) of low-income households received rebates under a program administered by Grid Alternatives. As discussed later, homes that were not in the CSI during the years the CSI was available appear to have installed much smaller systems. It is possible that the paperwork costs were greater than the rebate value for some customers. 
the incentives received under the Perfomance-Based Incentive (PBI). Of the systems under EPBB, the CSI database lists about 41,000 as residential and most of the rest as commercial. However, the PG\&E data of residential accounts includes many that are listed as commercial in the CSI database and have them on residential tariffs. I include these in the analysis. In total, about 48,000 premises appear in both the CSI database and the PG\&E residential solar PV data.

The PG\&E data include about 55,000 premises that do not appear in the CSI database as having CSI-program systems administered by PG\&E. For those households, I have only billing data plus the date of interconnection of the solar system and the size of the system. ${ }^{7}$ Having a measure of system size for the non-CSI systems allows some calculations of the incentives the owner could receive, but does not provide sufficient information to know all incentives or the cost of the system, so those systems are excluded from some of the analysis.

To focus on households with residential-size systems for which sufficient billing data exist I exclude any households with less than $0.5 \mathrm{~kW}$ or more than $20 \mathrm{~kW}$ solar capacity and any households with less than 365 days of billing data. I also exclude a small number of systems that were installed before 2007. This leaves 89,879 households with solar PV systems, of which 47,164 appear in the CSI database.

Based on U.S. census data, I then construct demographic data on the CBG of the household including the distribution of income in the CBG. ${ }^{8}$ As discussed below, I use a statistical matching approach from Borenstein (2012a) to estimate the income of particular households within a CBG.

I have 2006 to May 2014 billing data for nearly all new residential solar PV customers in PG\&E territory who had installed solar from 2007 to May 2014. Using these data and system size, I am able to construct counterfactual consumption levels for each premise and then estimate the customer's expected bill change from the solar installation.

7 Size of the system in these cases is the CEC-AC rating that PG\&E calculates based on the rated capacity of the panels and the specifications of the inverter. This rating does not take into account shading, direction, azimuth or panel efficiency. For about 5000 systems in the CSI, I also received the PG\&E value of CEC-AC rating. From those 5000 overlap systems, the CSI rating - which does account for these panel productivity factors - averages $91.5 \%$ of the CEC-AC rating. So for the systems not in the CSI, I use an estimated CSI rating equal to the CEC-AC rating multiplied by 0.915.

8 I use 2000 long-form census data, updated to 2007 by GeoLytics. The long-form census was completed by 1 in 6 households in 2000. Unfortunately, due to budget cuts and political opposition to census data collection, the long form was not used in 2010 . 


\section{Incentives to Install Residential Solar PV}

California began encouraging the installation of residential solar PV in the mid-1990s with direct and indirect subsidies. Through the tax code, the federal government has also created financial incentives for residential solar. Since 2007, the period I study, households installing solar PV have been eligible for a wide range of incentives. The most well known are the capacity-based rebates available under the California Solar Initiative and the federal tax credit for solar and other renewable energy sources. Somewhat less straightforward is the value of accelerated depreciation allowed under the federal tax code for solar systems owned by companies. And most indirect, but potentially important in magnitude, are incentives that result from the retail rate structure and the way that electricity from residential PV is treated under that structure. ${ }^{9}$

\section{Direct Rebates and Tax Credits}

Under the California Solar Initiative, customers were eligible for direct cash rebates based on the amount of PV capacity they installed. ${ }^{10}$ The CSI programs were administered at the utility level for the 3 large California investor-owned utilities (IOUs). Within each utility-territory program, the level of the rebate declined as the total capacity supported in the territory hit certain capacity milestones. The program began in 2007 with rebates of $\$ 2.50$ per watt of capacity and dropped to under $\$ 0.50$ in 2010 and eventually to zero in $2013 .{ }^{11}$ Figure 1 shows the rebates per watt of rated capacity received by PG\&E customers over time.

Households installing PV have also been eligible for a $30 \%$ federal tax credit on the cost of the system since 2007. Prior to 2009, however, the credit was capped at $\$ 2000$ when taken by an individual. A parallel program for business-owned systems - including systems placed on residential buildings and then leased to the homeowner or the power then sold to the homeowner under a power purchase agreement (PPA) - also had a 30\% tax credit,

9 It is worth noting that the federal tax credit and accelerated depreciation are also available to grid-scale solar development projects. In addition, grid-scale projects receive some other financial incentives that do not apply to residential solar.

10 Less than $1 \%$ of residential systems installed under the CSI chose instead to receive subsidies based on the system's actual electricity production in the first 5 years of operation (the PBI program).

11 In later years, there were a small number of systems covered under the low-income focused programs: SASH for single-family structures and MASH for multi-family buildings. I have not yet been able to reliably match these to the billing data, so these systems - about 1800 over the sample period - are not included in the analysis that uses CSI data. The SASH dwellings are included in the analysis that uses all residential installations in PG\&E territory. 


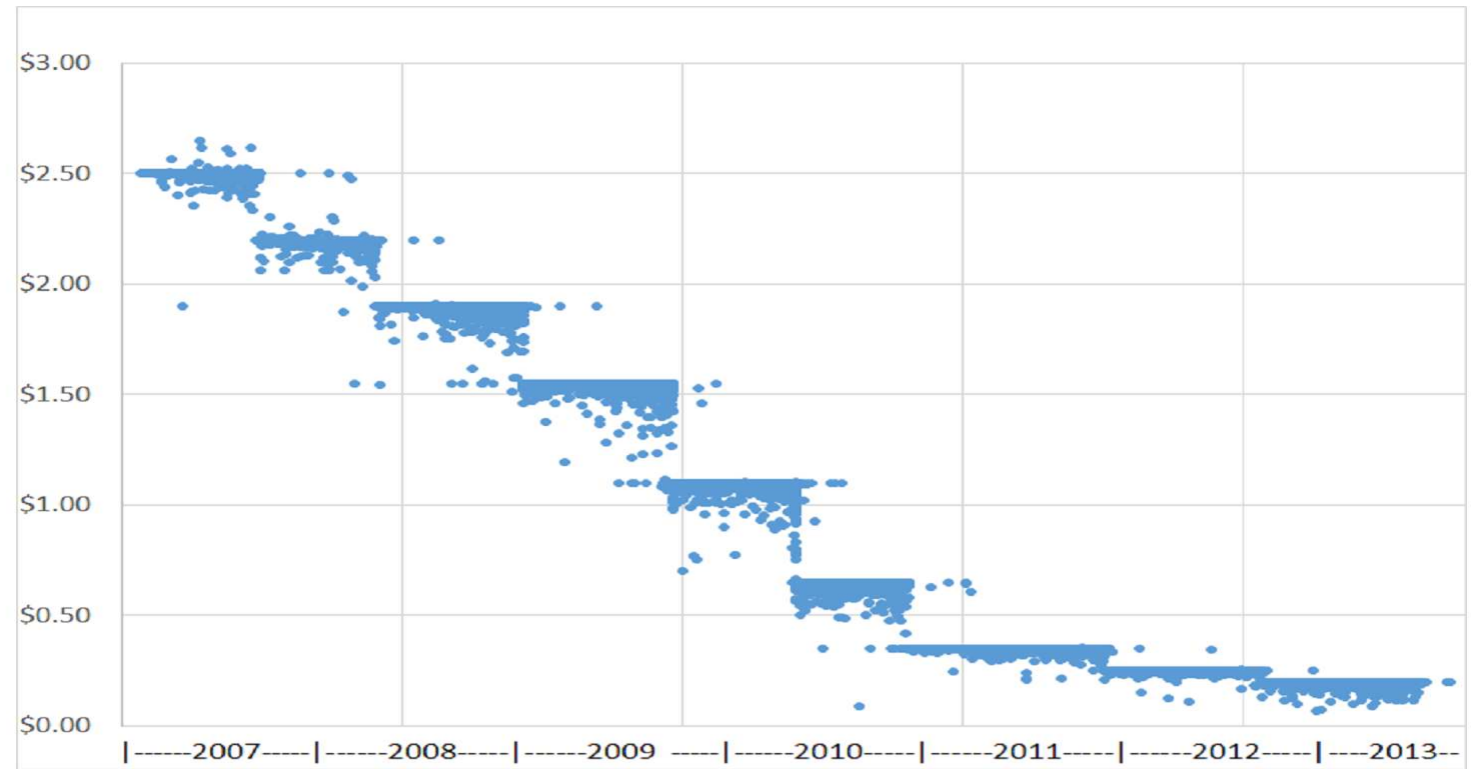

Figure 1: CSI rebates paid under PG\&E program over time

but with no cap in any years. From 2009 on, the residential tax credit was changed to have no cap, putting residential-owned and business-owned systems on an equal footing for the tax credit. I cannot calculate the federal tax credit for those systems not in the CSI database, because no data are available on the cost or the ownership of those systems.

Finally, there are three caveats on calculation of the federal tax credit. I am calculating it based on the cost of the system reported to the CSI. It is possible that this isn't the cost reported on tax forms, though there have also been reports of inflated cost reports under the CSI in order to justify higher tax credits. There are also two possible restrictions on the federal tax credit for residential installations. First, the credit is non-refundable and, as of now, cannot be carried forward beyond 2016. So the customer (or TPO) must have enough tax liability to absorb the credit. Second, the tax credit is subject to the limits of the Alternative Minimum Tax for individuals. I have no way of calculating the impact of these restrictions. Overall, my calculation of the federal tax credit incentive probably overstates its value somewhat, but it is not possible to estimate how much. ${ }^{12}$

\section{Accelerated Depreciation}

The tax treatment of business-owned systems continues to differ from household-owned in another important way: the use of accelerated depreciation. When an individual homeowner buys a solar PV system she does not pay taxes on the output of the system and she

12 As of this writing, the federal tax credit is scheduled to drop to $10 \%$ for businesses and $0 \%$ for residential customers on January 1, 2017. 
is not allowed to take a tax deduction for depreciation of the system. When a company owns the system, however, the income it earns leasing the system or selling energy under a PPA is taxable and the company can claim a tax deduction for depreciation of the system. In the simplest setting, if the overall operation of the firm generates zero economic profit and the depreciation that could be claimed exactly matched the economic depreciation, then these tax treatments would have no net effect on the economic cost to the customer. ${ }^{13}$

But if deductability is accelerated relative to the true economic depreciation, then this accelerated depreciation generates a tax advantage relative to ownership by the homeowner. The size of the tax advantage can be modeled based on the allowed depreciation relative to actual economic depreciation. However, other long-term capital investments are subject to 20-year depreciation even when they last much longer. Thus, in modeling the additional incentive effect of the allowed accelerated depreciation, I compare it to 20-year depreciation. ${ }^{14}$

Over the entire sample period I study, residential solar PV was eligible for 5-year accelerated depreciation. From 2008 to 2013, however, solar PV was allowed even more accelerated depreciation through a first-year "bonus" depreciation. In most of this period, the bonus depreciation was 50\%, meaning the firm takes $50 \%$ in the first year and depreciates the remaining $50 \%$ over years 1 through 5 . For systems placed in service after September 8, 2010 and before January 1, 2012, the bonus was 100\%, meaning that the firm could take the entire cost of a system as an expense in the first year. In the appendix, I model these implementations of accelerated depreciation under reasonable assumptions of the real interest rate, the inflation rate, and the form of depreciation. I find that accelerated depreciation is equivalent to a $12.6 \%$ to $15.2 \%$ reduction in the cost after state incentives and the federal tax credit. ${ }^{15}$ The direct beneficiary of the savings is the company that owns the PV system. The share of the value that flows to the homeowner, however, depends on the details of the lease or power purchase contract the customer signs. I do not have reliable information on these contracts. ${ }^{16}$ I calculate the accelerated depreciation

13 See Auerbach (1982) for an analysis of the economics of accelerated depreciation.

14 This seems appropriate if some investment will be made to produce this electricity and the alternative technology receives 20-year depreciation.

15 This is broadly consistent with calculations in a leaked 2010 White House memo that estimated a $\$ 1.9$ billion wind power project would generate $\$ 200$ billion in tax savings from accelerated depreciation. See page 8 of the memo, which is at http://abcnews.go.com/Blotter/page?id=12048229.

16 Another advantage of the leasing or power purchase arrangements is that the depreciation is based on the expected revenues to the firm rather than costs. In itself, this is tax neutral if expected revenues 
value for only the company-owned systems that are in the CSI database. For systems not in the CSI, I don't have the cost data or ownership information for this calculation.

\section{Rate Structure and Net Energy Metering}

The most indirect incentives for installing solar PV in California come from the residential rate structure and the way that residential PV is treated within that structure. IOUs in California - including PG\&E - collect virtually all residential customer revenue through increasing-block pricing, a volumetric charge that increases the marginal price per kilowatt-hour as the household's total consumption increases within a billing period. These residential rates have little or no fixed monthly charge or other non-volumetric charge. As a result, high-usage electricity consumers face very high marginal prices, which increases the return to installing PV. Throughout the period studied here, the rate structures had 4 or 5 tiers with lowest-tier prices in the range of $\$ 0.12-\$ 0.15$ and the highest-tier prices in the range of $\$ 0.28-\$ 0.48$. Even the lowest tier price is likely above the average long-run marginal cost of additional consumption of a residential customer. ${ }^{17}$ Figure 2 shows the average rate structure over the sample period for PG\&E.

Marginal retail rates well above marginal cost create a particularly potent incentive to install PV due to another policy known as Net Energy Metering (NEM). NEM, which California adopted in the 1990s, is often described as running the electricity meter backwards when the solar PV system is producing more electricity than the household is consuming. In financial terms, it means that the household is selling excess generation at any point in time back to the utility at the household's marginal retail electricity rate for the billing period.

In practice, if a household's monthly net consumption is positive, then a bill is calculated for that net consumption using the increasing-block rate schedule the household faces. If the net consumption is negative, the reverse happens with the negative amount given a dollar value using the normal rate schedule. Households on NEM are on a 12-month billing cycle. During their annual billing cycle, the household will pay a small monthly

exactly cover the cost of installation and operation, but there are widespread reports of the revenue estimates having been inflated in some cases. See Podolefsky (2013). I do not attempt to model the subsidy impact of this feature of the tax code. I do account for the fact that, despite the $30 \%$ tax credit, the basis for accelerated depreciation is $85 \%$ of the full cost, not $70 \%$. This seems to be the result of a fairly arbitrary decision to reduce the depreciation basis by half of the tax credit.

17 That is, if one evaluated the long-run marginal cost of an additional kilowatt-hour of consumption allocated proportionally to a customer's existing consumption in each hour of the year, the average additional cost per kilowatt-hour would likely be no higher than the lowest tier retail prices. I discuss this claim at greater length below. 


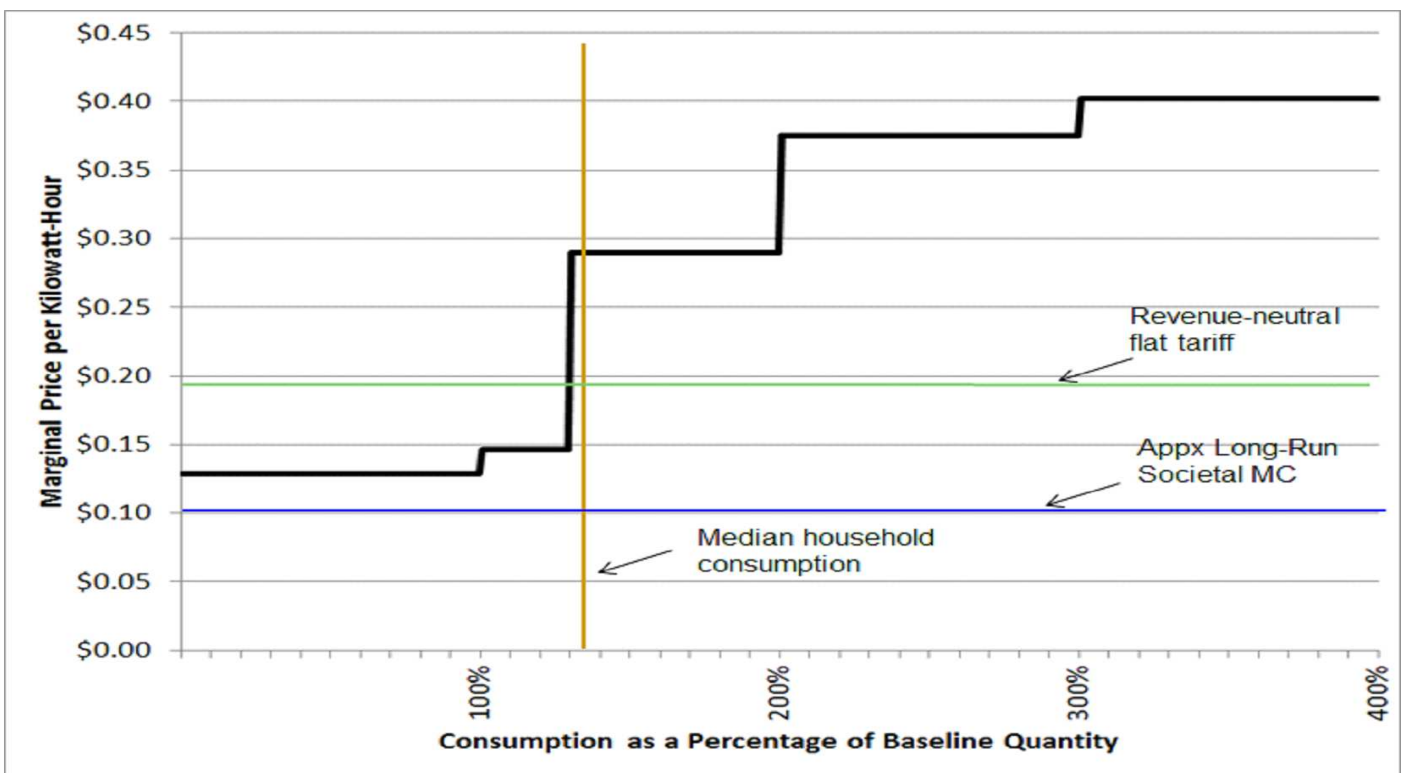

Figure 2: Average PG\&E increasing block pricing tariff during 2007-2013

bill that reflects only some of the non-usage based costs the utility incurs when serving the household. At the end of the annual billing cycle, there is a true-up process where the 12 months of credits and debits for the net electricity consumed are summed. If the household is a net consumer, it owes the utility for its net consumption. ${ }^{18}$ If it is a net exporter of electricity, prior to 2011 it earned zero compensation for the balance, but since 2011 the household is paid an amount based on the average day-ahead wholesale electricity price between $9 \mathrm{am}$ and $5 \mathrm{pm}$. Since 2011, this has been in the range of $\$ 0.035$ to $\$ 0.05$ per kilowatt-hour. About $5 \%$ of households with PV are net exporters over a 12 month period. In fact, as discussed below, solar PV systems are often designed to just replace consumption on the highest tiers of the increasing-block rate schedule.

Considering the impact of NEM is particularly important when one recognizes - as I discuss in more detail below - that typically more than one-third of the electricity generated by residential PV systems in California is not used on-site, but instead flows into the grid. ${ }^{19}$ If that electricity flowing to the grid were compensated at the day-ahead wholesale price, as is the policy for annual net generation, it would noticeably reduce the benefits of solar PV.

18 If the customer is on a time-of-use rate, the calculation is more complex. The net payment depends on when consumption from the grid occurs. The vast majority of solar PV customers are not on time-of-use rates. The calculations I show assume that all customers are on time-invariant rates.

19 See Darghouth et al (2011). 


\section{Incidence of Financial Incentives for Residential PV}

Although I calculate or estimate the size of each of these incentives, I do not attempt to evaluate how they are divided between buyers and sellers in the market. The great dispersion in prices and customization of each solar installation suggests that the market is unlikely to be well-characterized as perfectly competitive, so estimation of pass-through is especially difficult. Attempts by Podolefsky (2013), Henwood (2014), and Dong, Wiser and Rai (2014) come to widely varying conclusions of $17 \%, 45 \%$ and $99 \%$ of subsidies accruing to the buyers, respectively. Due to the complexity of contracts for solar installations, the incentive to mis-report transaction prices, and the opportunity to include ancillary construction services for strategic tax reasons, it is hard to know how the benefits of these financial incentives are actually apportioned. In addition, the residential solar industry is known for having very high customer acquisition costs, which may dissipate a significant share of the rents available from these incentives.

\section{The Income Distribution of Households Adopting PV}

Direct data on income or wealth of households installing solar PV are not available, but I do have information that locates each household in a census block group (CBG), an area that contains about 600 households on average. These data are combined with information from the 2000 census long form that estimates income distribution in categories that I have aggregated up to five brackets that correspond roughly to quintiles. ${ }^{20}$ The annual household income brackets are $\$ 0-\$ 20,000, \$ 20,000-\$ 40,000, \$ 40,000-\$ 60,000, \$ 60,000-\$ 100,000$, and above $\$ 100,000$, in 2000 dollars. This gives the income distribution in the CBG in which each solar PV system is located.

As Borenstein (2012a) discusses, in doing this sort of matching households to CBGs (or census tracts), historically nearly all research has associated each household with the median household income in the $\mathrm{CBG}$, but in fact there is substantial income heterogeneity within CBGs. Borenstein (2012a) develops a method of bounding distributional effects based on the full income distribution of households in each CBG and then develops a preferred estimate of each household's income bracket based on the household's electricity use and the correlation of rank in electricity usage with rank in income within CBGs. I use this method to derive a best estimate of each household's income. To be precise, I derive

20 The 2000 long-form data have been updated to 2007 with additional sampling by GeoLytics. I use the GeoLytics data for these calclations, but results are changed very little if the original 2000 census data are used. Unfortunately, the census long form was not funded by Congress for the 2010 census, instead replaced by the American Community Survey. The ACS has far less survey density, so cannot be used for this analysis. 
household income bracket estimates based on the preferred "weighted-rank method" presented in Borenstein (2012a). Within each CBG, this method associates larger electricity consumers with higher income in expectation. Borenstein (2012a) shows that this is an accurate assumption and that failure to make the adjustment would on average understate the income of larger consumers and, in this case, would understate the income of households installing solar PV. ${ }^{21}$

As always in using household income estimates it is important to recognize that income is not perfectly correlated with measures closer to public policy concerns, such as wealth or permanent income. Unfortunately, it is difficult to improve on reported income using census data.

These are not the first estimates of the distribution of income of households installing solar PV. Reports produced by the state's California Solar Initiative ${ }^{22}$, by Energy \& Environmental Economics (E3) consulting for the California Public Utilities Commission ${ }^{23}$, and by $\mathrm{PG \& E} \mathrm{E}^{24}$ have reported income estimates based on median household income at various areas of aggregation. The CSI report uses 2000 census data at the zip-code level, which are about 8 times larger than a census block group on average. The E3 study uses median income at the census tract level, which are about 3-4 times larger than census block groups. The E3 study uses 2010 census data, but estimates are based on the American Community Survey, which captures about $3 \%$ of all households, as opposed to about $17 \%$ captured by the long form 2000 census. The PG\&E study uses 2010 data at the census block group level. Most importantly, all three studies use median household income of the area of observation. They do not incorporate information from the distribution of income and the correlation between usage and income level within an area of observation. The CSI report suggests a sharp increase from 2007 to 2011 in the share of households in low-middle income zip codes that installed solar. Over the same period, the E3 study finds at census tract level a slight decline in the average income of households installing solar. The PG\&E analysis also covers 2007-2011 and finds a slight decline in the share of new solar installations installed in CBGs with high median household income within PG\&E

21 I have also done the analysis, however, using the income bracket from the random-rank method which makes no such association. The results are directionally the same, but attribute substantially less capacity to the highest income brackets.

22 California Solar Initiative Annual Program Assessment, June 2012

23 California Net Energy Metering Ratepayer Impacts Evaluation, October 2013

24 Buller, 2013 


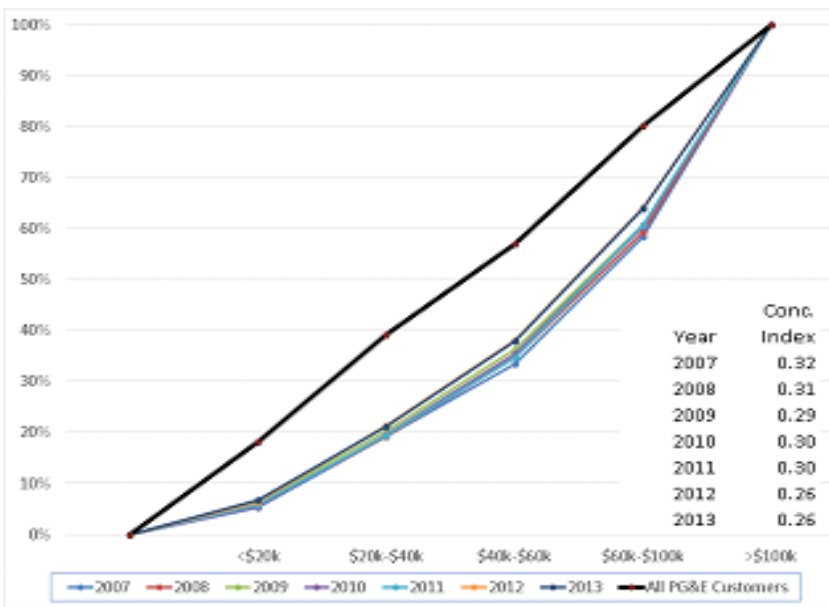

CSI Customers

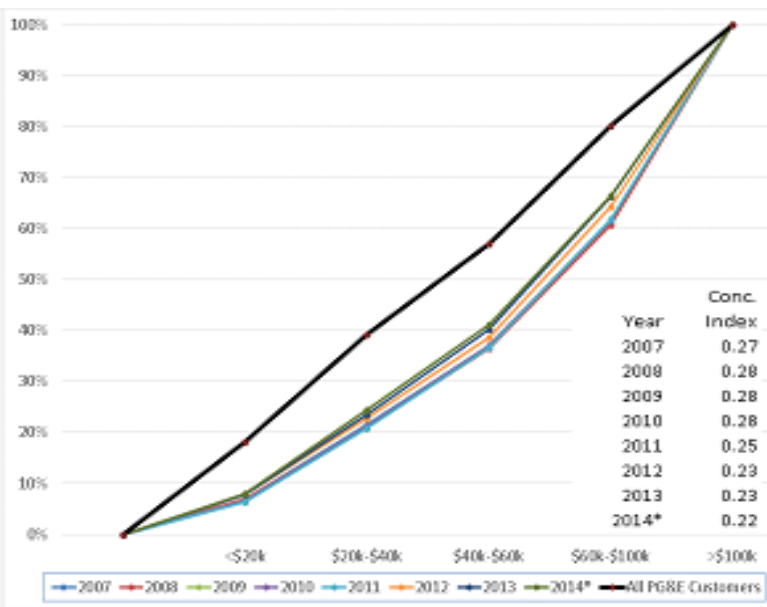

All Customers

Figure 3: Concentration Curves and Indexes of solar PV adopters by year

territory over that period.

The CSI-program results reported here are not directly comparable to the previous studies because I do not include the small number of systems on the low-income MASH and SASH programs. The broader results I present use the much-larger sample of all homes that interconnected during the sample period whether or not they received rebates under the CSI. As explained above, over the entire sample period, about half of all systems I study are included in the CSI. And the results reported here include data through 2013 and for part of 2014. My sample is slightly limited by the need to have sufficient electricity usage information to apply the within-CBG income matching method described above.

Figure 3 presents estimated concentration curves for the share of total systems installed for each income category, weighted by system capacity, as well as the the overall distribution of all households' incomes in PG\&E territory. ${ }^{25}$ The lefthand panel uses just CSI data for which the CEC system capacity rating is known (a total of 47,164 observations) from 2007 to 2013, while the righthand panel adds all other systems for which system capacity is inferred from the CEC-AC rating (89,879 observations) and includes data for the first 5 months of 2014. The concentration indexes for each year - measuring the share of area below the overall distribution line that is above the solar PV distribution line - are shown on the right. The concentration of PV in the highest income brackets has clearly declined over the sample period, with most of the change coming in the last couple years. Calculating the standard error of the estimated concentration index is complex, but it is straightforward

25 Concentration curves are closely related to Lorenz curves, but rank population on the horizontal axis by income (or other socio-economic variable) rather than by exposure to the variable on the vertical axis. For details see Maguire and Sheriff (2011). 
to calculate the mean income category of households installing PV (weighted by capacity). In both samples, a constant mean throughout the sample period is strongly rejected.

\section{The Private Net Benefits of Installing Solar}

I now turn to analyzing the benefits that households received from installing solar PV. To do this, I estimate all of the subsidies that were available to the household that were discussed in section III. This is not a complete list of possible subsidies, excluding, for instance, subsidies to low-income households and subsidies for solar in new homes which are not identified as PG\&E-administered CSI participants. With the current data, I cannot identify households in these other programs.

I also do not account for the value of renewable energy credits (RECs) that a solar PV system creates when it is installed. RECs for residential solar PV in California are of extremely low value, because the California Renewable Portfolio Standard effectively excludes them from being counted towards meeting the state's Renewables Portfolio Standard (RPS), and other states have thus far not accepted California residential solar RECs for their own RPSs, even in cases where in-state residential solar is included in their programs. It appears that RECs from California residential solar are purchased by electricity retailers as part of "greening up" their portfolios to well above the RPS requirement and by some companies as part of a decision to consume more renewable energy. ${ }^{26}$ These RECs are not traded in a public exchange, but industry media report trades at about $\$ 0.001$ cents per kWh. ${ }^{27}$

The incentives that I do estimate are the largest available to the typical residential PV adopter. For households not identified within the CSI, I also have no information of system cost or whether the system is third-party owned. Thus, for net benefit measures, I focus on households identified as having received CSI incentives through the PG\&E-administered branch of the CSI program.

CSI rebates are reported in the CSI data, as are the system prices that determine the federal tax credit. In 2009 and later years the full $30 \%$ credit could be claimed on personal as well as business tax returns. The CSI rebate is considered a price reduction for tax credit purposes if the owner is an individual. Therefore, the $30 \%$ tax credit applies to the after-rebate net price paid by the customer. For a company, however, the state rebate is

26 For instance, see Marin Clean Energy's Integrated Resource Plan, page 4. http://www.mcecleanenergy.org/wp-content/uploads/2014_Integrated_Resource_Plan.pdf

27 See, for instance, http://www.solarreviews.com/news/common-points-of-confusion-on-california-renewableenergy-credits-(recs)/. 
generally taxable income, in which case the basis for the $30 \%$ credit is then not reduced by the state rebate. These are equivalent if the business faces a $30 \%$ marginal tax rate. I don't know the actual tax rate of third-party business owners of residential systems, but the marginal corporate tax rate for firms above a fairly small size was $35 \%$ over this period, so I ignore this distinction and implicitly assume the $30 \%$ marginal tax rate.

The value of accelerated depreciation to a business depends on its cost of capital, the expected inflation rate, and the true economic depreciation of the solar panels, among other factors. These are all beyond data availability, so I assume the reasonable parameters discussed in the accelerated depreciation analysis in Appendix A and assume that accelerated depreciation reduces the effective system cost to businesses by $12.6 \%-15.2 \%$ depending on the first-year bonus depreciation.

The final incentive I estimate is due to electricity bill savings. This can be characterized as an incentive because the customer's private savings is greater than the utility's cost reduction when the customer reduces consumption. If that is the case, then to the extent that the customer's marginal price exceeds the utility's marginal cost, a share of the private savings from installing solar is a rent transfer rather than societal surplus creation. The size of that gap is, of course, quite controversial. If marginal price does exceed marginal cost, then net energy metering expands the quantity of electricity on which the rent transfer would occur.

I calculate the indirect incentive due to NEM and IBP based on the average price schedule over the sample period. ${ }^{28}$ I compare the customer's bill under the IBP schedule to the amount the same customer would have paid if she had faced a constant flat electricity tariff that raised the same revenue. ${ }^{29}$ That average cost pricing would yield a price of about $\$ 0.1905$ per $\mathrm{kWh}$, a price that is very likely above long-run marginal cost. So, I also calculate the economic incentive of the actual rate compared to a flat rate of $\$ 0.10$ per $\mathrm{kWh}$, a figure that is a plausible representation of long-run marginal cost, but would need to be augmented with a significant fixed or other charge in order to be revenue neutral. ${ }^{30}$

28 I have also done the calculations based on the tariff that was in place on the date the system was placed in service, but it makes almost no difference in the findings. It does, however, make it more difficult to examine the year-to-year variation in other aspects of the incentive. For that reason - and the fact that customers probably did not assume a rate frozen at the exact rate at the time of installation - I calculate incentives using the average retail rate over the sample period.

29 This assumes no net change in consumption among customers with solar.

30 The best estimates of long-run marginal cost from gas-fired generation is about $\$ 0.06 / \mathrm{kWh}$, but DG solar PV consumed onsite also avoids the 7\%-9\% of electricity that is dissipated through line losses as the power flows from generation through transmission and distribution lines to the end user. See 
Under NEM and IBP, the customer is compensated for PV generation, whether consumed on-site or injected into the grid, at the retail price of electricity. Under PG\&E's retail rates, the lowest marginal rate is for $\mathrm{kWhs}$ up to the baseline quantity, a quantity of electricity that differs across the 10 climate regions that span PG\&E's territory, but is the same for all residential customers within each climate region. ${ }^{31}$ Then there is a somewhat higher rate for an additional quantity equal to $30 \%$ of baseline. Beyond that the rate jumps substantially for the third tier that covers a quantity equal to $70 \%$ of baseline, and then it jumps again for all consumption beyond $200 \%$ of baseline. The exact rate changed numerous times during the sample period as wholesale electricity prices move, but the basic structure looks like figure 2. ${ }^{32}$ About half of all customers consume beyond the second tier. ${ }^{33}$ Because the marginal rate a customer faces is about 3 times higher on the highest block than on the lowest block, it is clear that the incentive to install solar PV is much greater for heavier-use households.

In order to calculate how much the retail rate structure enhances the incentive to install solar PV, one must also know the customer's consumption level. I use the confidential billing data to construct quantity consumed by month of year. I use three different methods, each imperfect in a different way, to estimate the customer bill savings from solar PV. The first approach uses pre-installation bill data to calculate average household usage prior to adopting solar PV. The second uses post-installation data and adds back in the expected production quantity from the solar PV system installed to get total household electricity consumption (including energy provided by their own solar PV). The solar PV production quantity comes from a simulation model that accounts for month-of-year and latitude of the household, and I then adjust for the efficiency rating of the system that was installed.

Borenstein (2008). Accounting for line losses, the electricity delivered for consumption from conventional generation has a marginal cost closer to $\$ 0.065 / \mathrm{kWh}$. The timing of power from solar PV also boosts its value, or the cost of alternative sources. Solar PV generation produces more at peak times, so it is replacing power at times when marginal electricity costs are higher. Borenstein (2008) estimates that in real-world grid operation this increases the cost of the alternative power source by an average of $20 \%$, bringing marginal cost of alternative generation to around $\$ 0.078 / \mathrm{kWh}$. Inclusion of the cost of GHG emissions raises the cost of alternative generation by slightly less than $\$ 0.02$ per $\mathrm{kWh}$ at a GHG price of $\$ 50 /$ ton, bringing the avoided marginal cost to about $\$ 0.10$.

31 The baseline is higher for "all-electric" households. I adjust for this in the very small number of households that are on "all-electric" rates.

32 Due to California legislation, the prices on the first two tiers were practically frozen during the sample period and all revenue adjustments came from moving the rates on the third and fourth tiers (and a fifth tier at some times) up or down.

33 See Borenstein (2012b). 
The first approach assumes that installing PV is not systematically associated with a change in consumption, which may not be the case. ${ }^{34}$ The second approach assumes that the simulation model for solar production is error free. Solar PV generation, however, varies due to shading and soiling of the panels, neither of which is captured very well in the simulation or the CEC rating. Both approaches assume that demand is price inelastic. To the extent that installing solar PV reduces quantity purchased from the utility and reduces the marginal price due to the IBP tariff, the first method understates the consumer surplus gains from installing PV and the second method overstates the gains. Based on Ito's (2014) finding that consumers facing IBP respond to average price more than marginal price and his estimate of a medium/long-run elasticity of -0.088, the surplus measurement error due to the quantity response to the change in price would be quite small compared to the overall surplus change.

The third approach combines the first two methods, estimating usage using both preand post-installation data. Each method is used only if at least one year of the appropriate data is available. I present results using the third method, but the three approaches yield substantially similar results. ${ }^{35}$

All of these estimates implicitly assume that the real price level and price structure will remain constant over time. That is unlikely to be the case, but there are many possible permutations of rate changes that would change the savings from a solar PV system. The real average price of residential electricity in California today is about the same as it was 30 years ago (based on data from the U.S. Energy Information Administration), but it has risen in PG\&E territory. Retail rates may be driven significantly by adoption of grid-scale renewable generation and the allocation of integration costs, but these costs are very difficult to predict. The other great uncertainty is the extent to which the IBP rate structure will be flattened over time. The ratio of higher to lower tier prices during the sample period is an extreme outlier compared to the rest of the U.S. Recently-passed

34 Installing PV could be associated with increases in consumption because it is part of a larger remodel of a house, because installing PV has a "moral licensing" effect that causes people to make less effort to restrain their electricity consumption, or because the marginal price the customer faces is lower after installing PV. It could be associated with lower consumption if PV is part of a broader adoption of sustainable energy practices that includes greater energy efficiency and conservation.

35 The tedious details of the usage calculation: For pre-solar installation data, for each billing period, a day's usage is assigned to be the average daily usage for the billing period in which the day occurs. The average usage on each day of the year (e.g., August 15) is taken to be the average of all the times that day of the year appears in the dataset for the household. Monthly usage for each calendar month is then calculated as the sum of the average usage on each day of the month. Bills are then calculated for each calendar month. The procedure for post-solar installation are the same except that the simulated average solar PV generation is added back to the billed quantity before these calculations are carried out. 


\begin{tabular}{|c|c|c|c|c|c|c|c|}
\hline Year & Lease or Buy & Obs & $\begin{array}{l}\text { Total } \\
\text { Price }\end{array}$ & $\begin{array}{r}\text { Capacity } \\
(\mathrm{kW})\end{array}$ & $\begin{array}{r}\text { CSI } \\
\text { Rebate }\end{array}$ & $\begin{array}{r}\text { Fed tax } \\
\text { Credit }\end{array}$ & $\begin{array}{r}\text { Accel Dep } \\
\text { Value }\end{array}$ \\
\hline 2007 & Buy & 2347 & $\$ 39,481$ & 3.90 & $\$ 9,377$ & $\$ 1,994$ & $\$ 0$ \\
\hline 2007 & Lease/PPA & 149 & $\$ 39,354$ & 3.95 & $\$ 9,224$ & $\$ 9,039$ & $\$ 3,227$ \\
\hline 2008 & Buy & 3739 & $\$ 41,103$ & 4.14 & $\$ 8,679$ & $\$ 1,998$ & $\$ 0$ \\
\hline 2008 & Lease/PPA & 508 & $\$ 49,613$ & 4.18 & $\$ 8,086$ & $\$ 12,458$ & $\$ 4,906$ \\
\hline 2009 & Buy & 5882 & $\$ 40,131$ & 4.24 & $\$ 6,830$ & $\$ 9,991$ & $\$ 0$ \\
\hline 2009 & Lease/PPA & 845 & $\$ 48,086$ & 4.46 & $\$ 7,253$ & $\$ 12,250$ & $\$ 4,824$ \\
\hline 2010 & Buy & 5037 & $\$ 37,934$ & 4.67 & $\$ 4,416$ & $\$ 10,055$ & $\$ 0$ \\
\hline 2010 & Lease/PPA & 2223 & $\$ 41,175$ & 4.66 & $\$ 4,283$ & $\$ 11,068$ & $\$ 4,544$ \\
\hline 2011 & Buy & 4414 & $\$ 33,444$ & 4.39 & $\$ 1,901$ & $\$ 9,463$ & $\$ 0$ \\
\hline 2011 & Lease/PPA & 4014 & $\$ 35,064$ & 4.19 & $\$ 1,764$ & $\$ 9,990$ & $\$ 4,302$ \\
\hline 2012 & Buy & 3388 & $\$ 28,591$ & 4.27 & $\$ 1,038$ & $\$ 8,266$ & $\$ 0$ \\
\hline 2012 & Lease/PPA & 7479 & $\$ 31,360$ & 4.68 & $\$ 1,135$ & $\$ 9,068$ & $\$ 3,571$ \\
\hline 2013 & Buy & 2114 & $\$ 29,170$ & 4.98 & $\$ 995$ & $\$ 8,453$ & $\$ 0$ \\
\hline 2013 & Lease/PPA & 5020 & $\$ 29,030$ & 4.62 & $\$ 920$ & $\$ 8,433$ & $\$ 3,32$ \\
\hline
\end{tabular}

Table 2a: Average cost and direct financial incentives for systems in CSI

\begin{tabular}{lrrrrrr} 
Year & Obs & $\begin{array}{r}\text { Capacity } \\
\text { (kW) }\end{array}$ & \multicolumn{4}{c}{ |--------NPV of 25-year Electricity Bill Savings ------- I } \\
& & & IBP with & IBP with & flat rate & MC \\
& & & & & & \\
& & & & & & \\
2007 & 5601 & 3.67 & $\$ 20,965$ & $\$ 18,223$ & $\$ 14,576$ & $\$ 7,650$ \\
2008 & 5701 & 3.73 & $\$ 21,628$ & $\$ 18,612$ & $\$ 14,829$ & $\$ 7,783$ \\
2009 & 8393 & 4.00 & $\$ 23,338$ & $\$ 19,794$ & $\$ 15,943$ & $\$ 8,368$ \\
2010 & 9110 & 4.42 & $\$ 26,270$ & $\$ 22,167$ & $\$ 17,634$ & $\$ 9,255$ \\
2011 & 11827 & 4.02 & $\$ 23,321$ & $\$ 19,972$ & $\$ 16,017$ & $\$ 8,407$ \\
2012 & 15182 & 4.17 & $\$ 23,556$ & $\$ 20,074$ & $\$ 16,630$ & $\$ 8,728$ \\
2013 & 25654 & 4.46 & $\$ 24,726$ & $\$ 21,024$ & $\$ 17,793$ & $\$ 9,339$ \\
$2014 *$ & 8411 & 4.65 & $\$ 25,729$ & $\$ 21,789$ & $\$ 18,600$ & $\$ 9,762$
\end{tabular}

Table 2b: Average bill savings under alternative tariffs for all PG\&E residential solar

legislation allows for a gradual flattening, and some has occurred since the end of the sample, but the actual tariffs that will be adopted are hard to forecast. For these reasons, I stick with a average price structure that was in existence over the 2007-2014 timeframe, in real 2014 dollars.

Table 2 presents summary statistics broken out by year of system installation and pur- 
chase versus lease/PPA. ${ }^{36}$ Throughout the sample period, lease/PPA arrangments have significant tax advantages over outright purchase by the homeowner, particularly in 20072008 when the federal tax credit was capped for homeowners. Yet, the lease/PPA model had a relatively small market share until the last few years of the sample. The incentives in the top panel of table 2 can be calculated only for systems that were part of the CSI, because data on cost are not available for other systems.

The bill savings shown in the bottom panel of table 2 are calculated for all systems in the billing data that meet the criteria discussed in section II. The 4 right-hand columns are the estimated net present value of bill savings based on each household's estimated monthly usage pattern and simulated generation from the installed solar PV system over the life of the system. I assume constant real electricity rates and consumption patterns, and a 25 year life of the system with the PV output declining by $0.5 \%$ of the original output each year, due to panel degradation. Throughout the calculations presented here, I assume a $4 \%$ real discount rate for all consumers. To the extent that lower-income consumers face higher interest rates than wealthier consumers, ignoring the difference will tend to overstate the NPV for lower-income customers relative to others.

The difference between these savings in the lower panel suggests the size of the additional incentive due to rate design. For systems installed in the first third (approximately) of 2014, the increasing-block pricing system implies an additional incentive averaging slightly over $\$ 7000$ compared to a revenue-neutral flat rate of $\$ 0.1905 / \mathrm{kWh}$. The additional incentive due to such tiered pricing averages about $\$ 16,000$ compared to charging a flat rate of $\$ 0.10 / \mathrm{kWh}$.

One might ask how much net metering increases the value of residential solar versus a system that reduces retail bills just for energy used on-site, but pays a wholesale price for energy injected into the grid. The answer would depend on how much of the electricity generated is injected into the grid. Darghouth et al (2011) present calculations of the share of electricity that would be considered injected into the grid under hourly, rather than monthly, net metering. This still understates injections, but may capture most of the effect. They show the share is an increasing function of the ratio of $\mathrm{PV}$ generation to customer load. At a $60 \%$ ratio, the average for my sample, figure 6 in Darghouth et al suggests about $30 \%$ of the PV generation would be injected into the grid. If that electricity were compensated at a marginal avoided cost of $\$ 0.10$, and the remainder reduced usage

36 For purchased systems, "price" is the purchase price. For leased systems, it is a constructed figure that is reported to the IRS for tax credit purposes. It is supposed to represent the fair market value of goods and services delivered under the lease contract. 


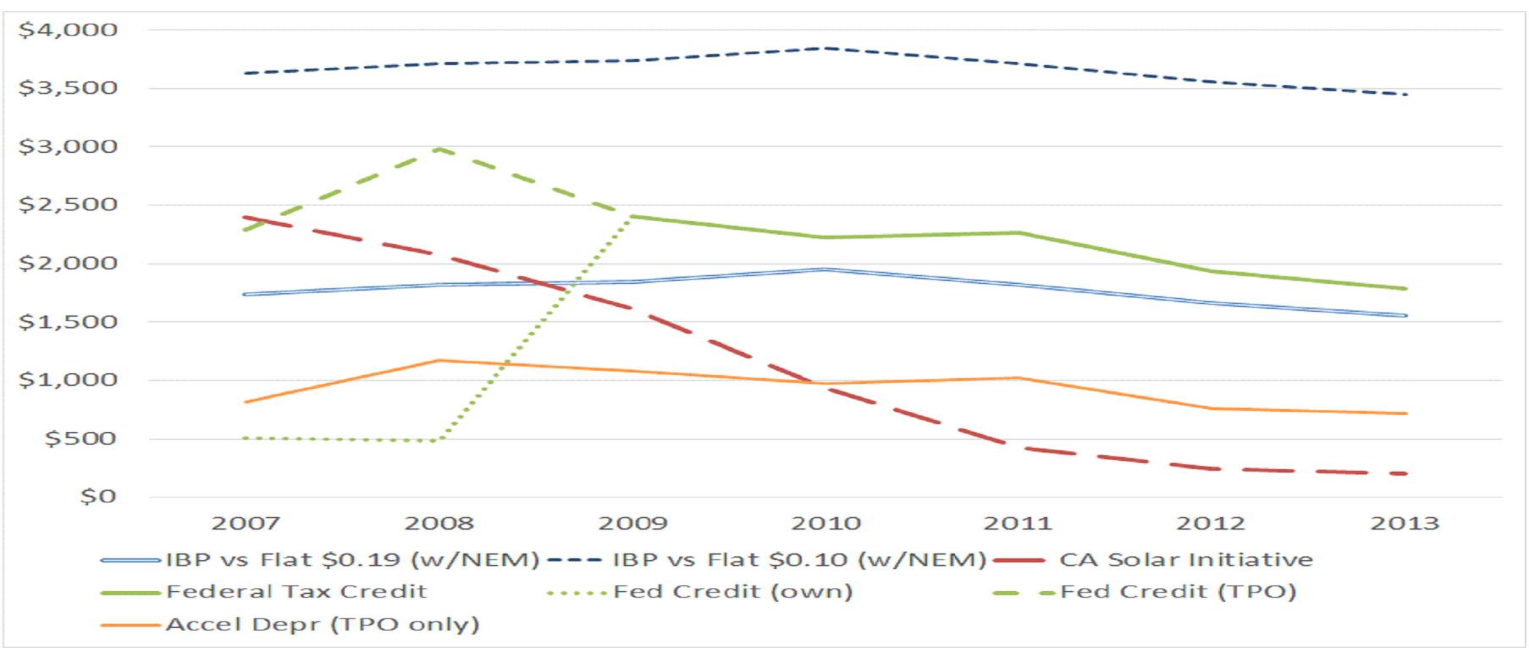

Figure 4: Average value of incentives for installing residential PV

billed under the IBP tariff, this would significantly lower the gains from installing solar. I carry out this calculation for every PG\&E residential PV system in the dataset and report the results for those in the CSI in the "IBP with hourly NEM" column of table $2 \mathrm{~b} .{ }^{37}$

Switching from annual netting to hourly netting has a smaller effect on bill saving than one might expect, because under IBP the solar generation would still displace the most expensive kWhs first, so the electricity now compensated at marginal avoided cost is the least expensive electricity that the solar PV system would have displaced. For instance, if the system is large enough to lower the customer's net consumption into the first or second tier, then switching to hourly net metering would change the customer's compensation from the $\$ 0.12-\$ 0.15$ avoided charge to the $\$ 0.10$ wholesale payment.

Figure 4 summarizes the major incentives available to residential PV adopters per kilowatt of capacity installed. In 2007 and 2008 - a time in which most systems were purchased by the homeowner so qualified for very limited federal tax credits - the CSI played a larger financial role in promoting residential solar than the federal tax credit or the IBP rate structure compared to a revenue-neutral flat rate. From 2009 on, however, the CSI role rapidly diminished and the federal tax credit and tiered rate structure were far more powerful mechanisms. The federal tax credit, of course, was available throughout the U.S., but the extremely high marginal rates faced by heavy consumers in California were unmatched in the continental U.S.

37 The calculation for each household is based on that household's ratio of PV generation to annual consumption and matched to the "hourly netting" function displayed in figure 6 of Dargouth et al (2011). 


\section{Differences in Private Benefits Across Income Brackets}

Using the estimated income brackets discussed in section IV, I now examine how solar systems differ across the households of different income levels that install them. Table 3 presents descriptive regressions of customer and system attributes on income brackets and year-of-installation fixed effects. The omitted income category is the wealthiest bracket and the omitted year is 2013 .

Not surprisingly, column (1) shows lower-income customers install smaller systems on average and column (2) demonstrates they consume less on average. ${ }^{38}$ Column (3) considers the ratio of $\mathrm{PV}$ generation to consumption and shows lower-income customers who adopt PV produce more electricity onsite relative to their annual consumption. The wealthiest income bracket installed systems that displaced about $57 \%$ of their consumption, while the figure was higher for all other income brackets about 26 percentage points higher for the poorest income bracket. Thus, lower-income PV adopters both start from a lower tier of the increasing-block price schedule and displace a larger share of their consumption with their PV systems than do richer customers.

Column (3) doesn't control for month of usage, month of PV production, or climate zone (and associated baseline quantity) of the household, but column (4) does. The dependent variable in column (4) is the household's average savings per $\mathrm{kWh}$ their system produces or, put differently, the average price of the $\mathrm{kWh}$ purchase that is displaced by onsite PV generation. The constant of 0.272 means that under PG\&E's average increasing-block tariff over the sample period, the highest-income bracket PV adopters in 2013 would have expected that their onsite PV production would reduce their bill by 27.2 cents per $\mathrm{kWh}$ on average. This number is 5.9 cents lower for the lowest-income bracket, about $22 \%$ lower. Compared to the highest-income households installing PV, the savings for next to lowest bracket are $12 \%$ smaller per $\mathrm{kWh}$ produced, $8 \%$ smaller for the middle income bracket, and $7 \%$ smaller for next-to-highest bracket.

Finally, column (5) of table 3 shows the same regression as a linear probability model for the own versus lease/PPA decision, employing only data on customers in the CSI, for whom the own/lease information is available. Leases and PPAs have been widely discussed as a way for lower income households to get into solar without the upfront costs. Through

38 These results are, in part, mechanically a result of the weighted-rank within-CBG income bracket matching technique described in the previous section, but they also hold even using the random-rank approach. However, the random-rank approach fails to capture the fact that within census block groups higher-use consumers are on average wealthier. 


\begin{tabular}{|c|c|c|c|c|c|}
\hline VARIABLES & $\begin{array}{c}(1) \\
\text { PV Capacity } \\
(\mathrm{kW})\end{array}$ & $\begin{array}{c}(2) \\
\text { Annual } \\
\text { Consump (kWh) }\end{array}$ & $\begin{array}{c}\text { (3) } \\
\text { PV generation } \\
\text { Consumption }\end{array}$ & $\begin{array}{c}\text { (4) } \\
\text { Average Price of } \\
\text { kWh Displaced }\end{array}$ & $\begin{array}{c}(5) \\
\text { Lease/PPA } \\
\text { Share }\end{array}$ \\
\hline Constant & $\begin{array}{l}4.687 * * * \\
(0.0684)\end{array}$ & $\begin{array}{c}12,235 * * * \\
(176.1)\end{array}$ & $\begin{array}{r}0.572 * * * \\
(0.0192)\end{array}$ & $\begin{array}{l}0.272^{* * *} \\
(0.00159)\end{array}$ & $\begin{array}{l}0.716 * * * \\
(0.00868)\end{array}$ \\
\hline Income bracket 1 & $\begin{array}{l}-0.772^{* * *} \\
(0.0676)\end{array}$ & $\begin{array}{c}-3,363^{* * *} \\
(203.5)\end{array}$ & $\begin{array}{l}0.263^{* * *} \\
(0.0988)\end{array}$ & $\begin{array}{c}-0.0587^{* * *} \\
(0.00214)\end{array}$ & $\begin{array}{c}-0.0525 * * * \\
(0.0115)\end{array}$ \\
\hline Income bracket 2 & $\begin{array}{l}-0.347^{* * *} \\
(0.0529)\end{array}$ & $\begin{array}{c}-1,670^{* * *} \\
(182.4)\end{array}$ & $\begin{array}{l}0.0959 * * * \\
(0.0328)\end{array}$ & $\begin{array}{c}-0.0317 * * * \\
(0.00172)\end{array}$ & $\begin{array}{c}-0.0335^{* * *} \\
(0.00932)\end{array}$ \\
\hline Income bracket 3 & $\begin{array}{c}-0.268^{* * *} \\
(0.0485)\end{array}$ & $\begin{array}{c}-1,234 * * * \\
(146.2)\end{array}$ & $\begin{array}{c}0.0491 * * * \\
(0.0103)\end{array}$ & $\begin{array}{c}-0.0229 * * * \\
(0.00151)\end{array}$ & $\begin{array}{l}-0.0175^{*} \\
(0.00913)\end{array}$ \\
\hline Income bracket 4 & $\begin{array}{c}-0.234 * * * \\
(0.0389)\end{array}$ & $\begin{array}{c}-1,064 * * * \\
(117.8)\end{array}$ & $\begin{array}{l}0.0321 * * * \\
(0.00579)\end{array}$ & $\begin{array}{c}-0.0184 * * * \\
(0.00119)\end{array}$ & $\begin{array}{l}-0.00416 \\
(0.00738)\end{array}$ \\
\hline yr2007 & $\begin{array}{l}-0.801 * * * \\
(0.0705)\end{array}$ & $\begin{array}{l}-182.8 \\
(185.3)\end{array}$ & $\begin{array}{c}-0.0907 * * * \\
(0.0269)\end{array}$ & $\begin{array}{c}0.00203 \\
(0.00216)\end{array}$ & $\begin{array}{l}-0.645^{* * *} \\
(0.00893)\end{array}$ \\
\hline yr2008 & $\begin{array}{c}-0.740^{* * *} \\
(0.104)\end{array}$ & $\begin{array}{c}31.39 \\
(234.4)\end{array}$ & $\begin{array}{l}-0.0137 \\
(0.0828)\end{array}$ & $\begin{array}{l}0.00135 \\
(0.00254)\end{array}$ & $\begin{array}{l}-0.585^{* * *} \\
(0.0104)\end{array}$ \\
\hline yr2009 & $\begin{array}{l}-0.466 * * * \\
(0.0785)\end{array}$ & $\begin{array}{l}-36.94 \\
(216.5)\end{array}$ & $\begin{array}{l}-0.0443^{*} \\
(0.0235)\end{array}$ & $\begin{array}{c}0.00197 \\
(0.00238)\end{array}$ & $\begin{array}{l}-0.578 * * * \\
(0.00939)\end{array}$ \\
\hline yr2010 & $\begin{array}{l}-0.0550 \\
(0.0540)\end{array}$ & $\begin{array}{c}778.3^{* * *} \\
(147.4)\end{array}$ & $\begin{array}{c}-0.0632 * * * \\
(0.0230)\end{array}$ & $\begin{array}{l}0.0119 * * * \\
(0.00151)\end{array}$ & $\begin{array}{l}-0.398 * * * \\
(0.0136)\end{array}$ \\
\hline yr2011 & $\begin{array}{l}-0.442^{* * *} \\
(0.0480)\end{array}$ & $\begin{array}{c}125.7 \\
(187.0)\end{array}$ & $\begin{array}{l}-0.000425 \\
(0.0524)\end{array}$ & $\begin{array}{c}0.00760^{* *} \\
(0.00312)\end{array}$ & $\begin{array}{c}-0.228 * * * \\
(0.0152)\end{array}$ \\
\hline yr2012 & $\begin{array}{c}-0.284 * * * \\
(0.0408)\end{array}$ & $\begin{array}{l}-77.53 \\
(121.6)\end{array}$ & $\begin{array}{l}-0.0356 \\
(0.0225)\end{array}$ & $\begin{array}{l}0.00185 \\
(0.00167)\end{array}$ & $\begin{array}{l}-0.0155 \\
(0.0122)\end{array}$ \\
\hline Yr2014 & $\begin{array}{l}0.187 * * * \\
(0.0370)\end{array}$ & $\begin{array}{c}113.0 \\
(94.72)\end{array}$ & $\begin{array}{l}-0.00992 \\
(0.0255)\end{array}$ & $\begin{array}{c}-0.00107 \\
(0.000901)\end{array}$ & \\
\hline $\begin{array}{l}\text { Observations } \\
\text { Standard errors, }\end{array}$ & $\begin{array}{l}89,879 \\
\text { red at zip co }\end{array}$ & $\begin{array}{c}89,879 \\
\text { parentheses }\end{array}$ & $\begin{array}{l}89,879 \\
* * * p<0.01\end{array}$ & $\begin{array}{c}89,879 \\
* p<0.05^{*} p<0.1\end{array}$ & 47,164 \\
\hline
\end{tabular}

Table 3: Descriptive regressions of customer and system attributes

2013, however, in these data there was actually a statistically greater tendency for wealthier households to make use of the lease/PPA option. Still, with an overall rate of about $70 \%$ in 2013, the rate differed by only a few percentage points across income brackets, so it appears that this has become the dominant financial arrangement in all income brackets.

\section{Solar PV Pricing}

The net benefits from installing solar will also depend on the price the customer pays. To investigate this, I narrow the sample to just systems purchased by the homeowner, excluding leases and PPAs. Though "Total Cost" is reported in the CSI database for TPO systems, that entry is not a transaction price, as it is with systems that are sold. Rather, it is the seller's estimate of the "fair market value" of the contracted goods and services. In the case of PPAs, the more common form of contract, it incorporates an estimate of the value of the energy, as well as the value the consumer receives from the option to purchase the system, generally after 15 or 20 years, and the value of ongoing maintenance and repair. It's hard to know how to interpret these figures - particularly when they also 
affect the federal tax credit, creating incentives to distort the number. ${ }^{39}$ For these reasons, I focus on 27,292 systems in the CSI database that are owned by the household. These are not a random sample of systems, of course, but it is unclear how the selection into household system ownership affects the pricing of those systems. ${ }^{40}$

I estimate a pricing equation that allows for a fixed component and a quadratic function of system size. Two indicators of customer willingness-to-pay are also included: income bracket and annual usage. These are positively correlated, both in reality and by construction of the income bracket variable. Yet, their effects are strongly and separately significant. Income bracket is included as an integer from 1 , the lowest bracket, to 5 , the highest. ${ }^{41}$ Table 4 also shows results with income bracket interacted with system size, allowing for income to affect the marginal price of extra capacity rather than a constant change for all systems. Finally, I include fixed year effects interacted with system size. ${ }^{42}$

Of course, estimating a pricing equation with a quantity measure on the right-hand side raises issues of endogeneity and bias. While price increases with system size, higher price for a marginal kilowatt of capacity would likely cause the buyer to constrain the size of the system to some extent. I don't have a great instrument at this point, so instead interpret the results in light of this possible bias.

Perhaps surprisingly, the positive coefficient on PV capacity ${ }^{2}$ suggests an increased system size has an increasing marginal price. Using the coefficients in column (4), average price per kilowatt of capacity still falls with capacity out to about $11 \mathrm{~kW}$ capacity (varying somewhat with the year, income and annual consumption) due to the fixed cost component estimated in the constant term, but marginal cost increases by about $\$ 100 / \mathrm{kW}$ with every $1 \mathrm{~kW}$ increase in system size. This could be due roof capacity constraints. Note that this effect is in the opposite direction than the bias one would expect to find from typical endogeneity, where lower marginal price is associated with higher quantity. ${ }^{43}$

39 Podolefsky (2013) finds 8\% higher reported price for comparable systems under third-party ownership.

40 Gillingham et al (2014) estimate a system pricing equation using data from many states and incorporating many more variables, including measures of supply side variables on installer competition and experience. Each approach has its advantages. The analysis presented here includes detailed information on customer usage, but does not include multi-state observations and focuses only on residential systems.

41 Results are similar with fixed effects for each income bracket.

42 Including fixed year effects without system size interaction yields similar results for the other variables.

43 Gillingham et al (2014) find that average price per kW of capacity falls with capacity out to about $8 \mathrm{~kW}$ 


\begin{tabular}{|c|c|c|c|c|}
\hline VARIABLES & $\begin{array}{c}(1) \\
\text { totalcost }\end{array}$ & $\begin{array}{c}(2) \\
\text { totalcost }\end{array}$ & $\begin{array}{c}(3) \\
\text { totalcost }\end{array}$ & $\begin{array}{c}(4) \\
\text { totalcost }\end{array}$ \\
\hline Constant & $\begin{array}{c}5,583 * * * \\
(317.1)\end{array}$ & $\begin{array}{c}3,947 * * * \\
(454.8)\end{array}$ & $\begin{array}{c}5,056 * * * \\
(335.4)\end{array}$ & $\begin{array}{c}5,873 * * * \\
(765.3)\end{array}$ \\
\hline PV capacity & $\begin{array}{c}4,440^{* * *} \\
(192.4)\end{array}$ & $\begin{array}{c}4,017 * * * \\
(179.3)\end{array}$ & $\begin{array}{c}3,710^{* * *} \\
(151.8)\end{array}$ & $\begin{array}{c}3,574 * * * \\
(191.3)\end{array}$ \\
\hline PV capacity ${ }^{2}$ & $\begin{array}{c}47.85 * * * \\
(17.48)\end{array}$ & $\begin{array}{c}53.77 * * * \\
(17.13)\end{array}$ & $\begin{array}{c}51.75^{* * *} \\
(17.32)\end{array}$ & $\begin{array}{c}50.28 * * * \\
(18.48)\end{array}$ \\
\hline Annual Consumption & & $\begin{array}{c}0.200 * * * \\
(0.0239)\end{array}$ & $\begin{array}{c}0.198 * * * \\
(0.0227)\end{array}$ & $\begin{array}{r}0.198 * * * \\
(0.0228)\end{array}$ \\
\hline Income Bracket & & $\begin{array}{c}314.4^{* * *} \\
(62.93)\end{array}$ & & $\begin{array}{l}-238.3 \\
(257.4)\end{array}$ \\
\hline PV Cap * Income Bracket & & & $\begin{array}{c}89.42^{* * *} \\
(27.13)\end{array}$ & $\begin{array}{l}130.9^{*} \\
(70.06)\end{array}$ \\
\hline PV Cap * yr2007 & $\begin{array}{c}4,225 * * * \\
(335.6)\end{array}$ & $\begin{array}{c}4,156^{* * *} \\
(342.0)\end{array}$ & $\begin{array}{c}4,158 * * * \\
(342.6)\end{array}$ & $\begin{array}{c}4,161 * * * \\
(339.7)\end{array}$ \\
\hline PV Cap * yr2008 & $\begin{array}{c}3,921 * * * \\
(65.18)\end{array}$ & $\begin{array}{c}3,839 * * * \\
(65.41)\end{array}$ & $\begin{array}{c}3,841 * * * \\
(64.93)\end{array}$ & $\begin{array}{c}3,843 * * * \\
(64.30)\end{array}$ \\
\hline PV Cap * yr2009 & $\begin{array}{c}3,414 * * * \\
(73.09)\end{array}$ & $\begin{array}{c}3,360 * * * \\
(74.66)\end{array}$ & $\begin{array}{c}3,364 * * * \\
(74.16)\end{array}$ & $\begin{array}{c}3,366 * * * \\
(73.69)\end{array}$ \\
\hline PV Cap * yr2010 & $\begin{array}{c}2,154 * * * \\
(63.42)\end{array}$ & $\begin{array}{c}2,110^{* * *} \\
(63.11)\end{array}$ & $\begin{array}{c}2,113^{* * *} \\
(63.06)\end{array}$ & $\begin{array}{c}2,115^{* * *} \\
(63.00)\end{array}$ \\
\hline PV Cap * yr2011 & $\begin{array}{c}1,627^{* * *} \\
(66.73)\end{array}$ & $\begin{array}{c}1,585 * * * \\
(66.83)\end{array}$ & $\begin{array}{c}1,586^{* * * *} \\
(66.74)\end{array}$ & $\begin{array}{c}1,587 * * * \\
(66.67)\end{array}$ \\
\hline PV Cap * yr2012 & $\begin{array}{c}566.2 * * * \\
(75.33)\end{array}$ & $\begin{array}{c}553.6 * * * \\
(74.39)\end{array}$ & $\begin{array}{c}559.2 * * * \\
(73.75)\end{array}$ & $\begin{array}{c}561.0^{* * *} \\
(73.42)\end{array}$ \\
\hline R-squared & 0.772 & 0.775 & 0.775 & 0.775 \\
\hline
\end{tabular}

Table 4: Regressions of Solar PV Price (for purchased systems)

The impact of annual electricity usage and household income bracket are both very statistically and economically significant. A one standard deviation increase in annual consumption raises the price of the system by about $\$ 1400$, or about $4 \%$ at the mean. High usage households are displacing more expensive electricity due to increasing-block pricing, so receive more value from the system. It appears that sellers recognize this impact and capture some of those rents.

Likewise, for a given system size and household usage, customers in a higher income bracket pay more. Estimated as a simple price shift, it is estimated to add about $\$ 314$ for each income bracket increase. Column (3) estimates this impact as a change in the marginal price, suggesting each income bracket increase raises price by $\$ 89$ per $\mathrm{kW}$ of capacity. Estimating both a fixed and a per-kW effect together in Column (4) causes some collinearity, but it appears that higher income increases cost for systems above about 2 $\mathrm{kW}$ capacity.

and then increases. 
Together these results suggest that residential solar PV pricing exhibits at least some imperfect competition, with sellers able to price discriminate and extract higher prices from customers who receive greater savings from the system and may generally have higher willingness to pay. This of course does not mean that PV sellers are making extranormal profits. It is quite possible that any rents captured by sellers are dissipated in excess entry or competition among sellers for customer acquisition.

\section{The Private Net Present Value of Installing Solar}

Finally, I turn to the private net present value of the solar PV investment for those who have installed systems. As explained earlier, the potential savings to the consumer are calculated under three different tariffs, an increasing-block pricing tariff that was typical of the structure in place during the sample period, a flat rate-tariff that recovers the same revenue (under a zero-elasticity assumption), and a much lower flat-rate tariff that more closely reflects the marginal cost of supplying power from the grid. All of these rates are assumed to remain constant in real terms. I align monthly estimated usage - which I assume is unchanging over the assumed 25-year life of the system - with monthly PV generation to accurately capture the kilowatt-hours displaced by the solar PV generation under net energy metering. This does not affect the savings calculations under flat rates, but has a significant effect under increasing-block pricing.

I assume that the customer pays the price shown in the CSI database - again confining the analysis to systems owned by the household, not by third parties. The customers are assumed to make full payment for the system and receive full rebate and tax credit in the year of purchase. The calculation accounts for the actual CSI rebate the customer received and for the changes in the federal tax credit available at the time the system goes into operation. I assume that the system lasts 25 years (with production decreasing at $0.5 \%$ of original output each year), and that the customer owns the residence for the life of the system (or that the electricity savings value of the solar PV is exactly capitalized into any sale of the residence). Finally, I assume that every customer has a $4 \%$ real cost of funds. This assumption almost certainly biases the results towards more favorable outcomes for low income households relative to wealthier ones, because in reality low-income customers are likely to face a higher interest rate. Any assumption of an interest rate differential would be fairly arbitrary, however, so I adopt the $4 \%$ rate for all.

The resulting average net present values per kilowatt of capacity installed are shown in figure 5a for the average increasing-block pricing tariff and current net metering policy. The high-income customers are also the highest consumers so they crowd out the highestprice energy with their solar PV installations. Figure 5a shows this outweighs the higher 
Figure 5a: NPV per kW of systems installed under increasing block pricing with monthly net metering

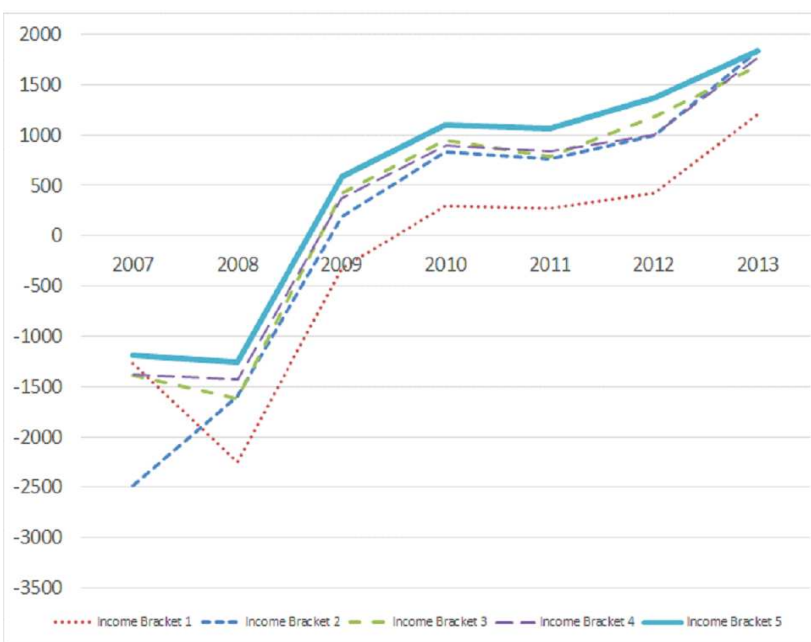

Figure 5b: NPV per kW of systems installed under increasing block pricing with hourly net metering

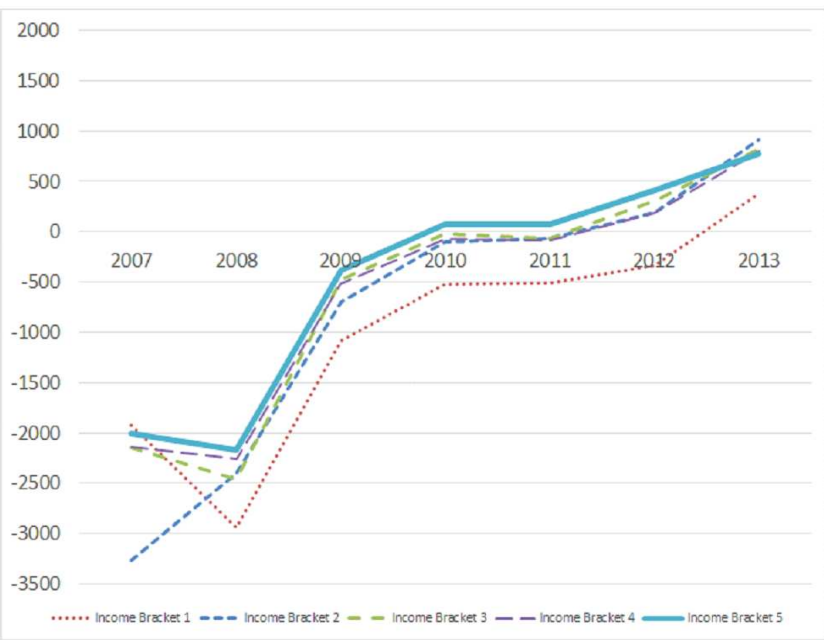

prices that these customers pay. As suggested earlier, the lowest income bracket has few customers, but their average NPV is consistently more negative. The NPV for all income brackets turns positive by 2010, but the average benefits per unit of capacity installed are consistently larger (more positive) for the higher-income households. This appears to change in 2013, however, for all groups but the lowest-income bracket.

Figure 5b shows the impact of net metering. Using the estimates of share of PV power used onsite from Darghouth et al (2011), figure 5b shows the estimated average NPV under hourly net metering adjusting for the size of each system relative to that household's consumption. The calculations assume that any excess generation within an hour is credited to the household at the assumed marginal avoided cost of $\$ 0.10 / \mathrm{kWh}$. This change lowers the net present value.

Figure 5c shows the same calculations as in 5a except assuming a flat retail rate of $\$ 0.1905 / \mathrm{kWh}$, which would be revenue neutral under zero elasticity. Flattening the rate lowers the value for households in all income brackets who have installed solar, but it has a greater negative impact on the highest-income households, because they are disproportionately using solar to displace higher-tier consumption. For the same reason, the impact on the average NPV of solar for lower-income households is much smaller. Of course, flattening the retail rate actually improves the average NPV of solar for customers who consume only on the first and second tier, though they are a very small share of solar adopters.

Lastly, figure $5 \mathrm{~d}$ shows the results for a marginal retail price of $\$ 0.10 / \mathrm{kWh}$, an approximation of the long-run marginal cost, including the externalities, from a natural gas-fired 
Figure 5c: NPV per kW of systems installed under flat pricing $(\$ 0.19 / \mathrm{kWh})$ with monthly net metering

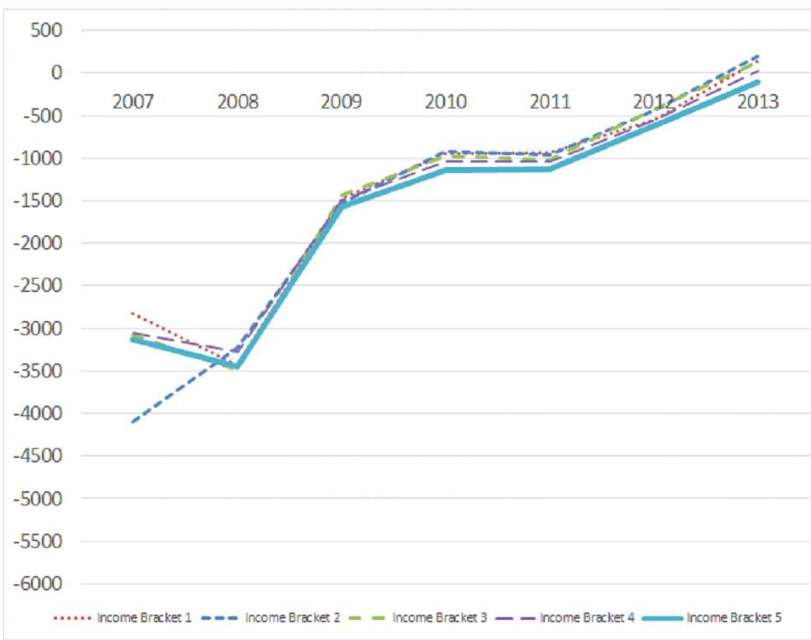

Figure 5d: NPV per kW of systems installed under flat pricing at appx. social marginal cost $(\$ 0.10 / \mathrm{kWh})$

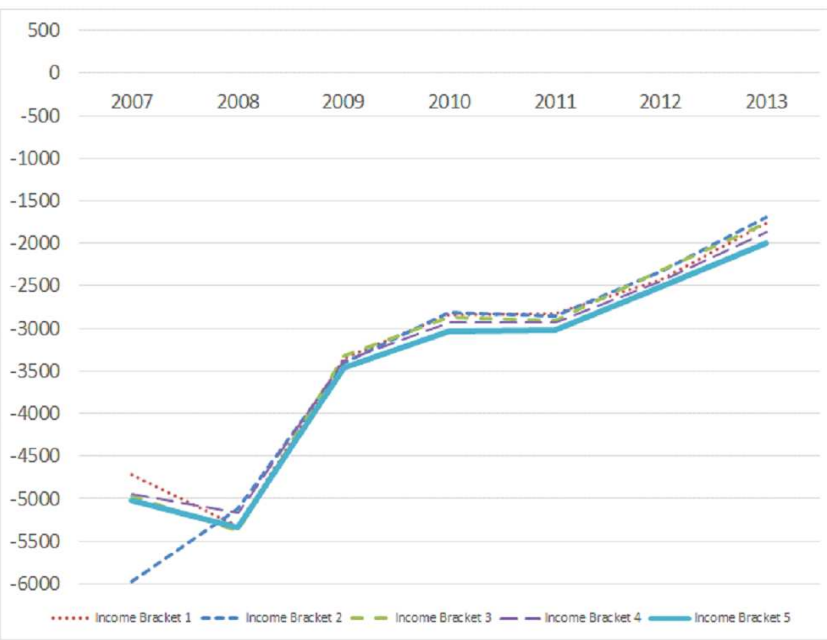

power plant. This is just a downward shift of the lines in figure 5c, but it highlights the fact that a two-part tariff that set marginal price equal to social marginal cost would make the economics of solar PV much less attractive, even with the federal tax credits.

\section{Conclusion}

It is, of course, not a surprise that most households installing solar PV are relatively affluent. Until the past few years, the cost of residential solar was so high that even with aggressive rebates and tax incentives it was still not a choice that most customers could justify on finances alone. In California, however, the retail rate structure has tilted the buyer profile even more in the direction of large uses, who are disproportionately wealthy. I estimate that in 2013, the average net present value of the lifetime savings from installing residential solar was nearly $\$ 7000$ greater under the increasing-block pricing structure than it would have been under a flat rate structure. That additional incentive is more than the CSI rebate at any time except the first two years of the program, and nearly as large as the $30 \%$ federal tax credit.

I find that the income distribution of solar PV installations remains heavily skewed towards the wealthy, but somewhat less so in the last few years with some evidence of the gap narrowing further in 2014. While lease and PPA arrangement are argued to help lowerincome customers get into solar, I find evidence of slightly lower use of such arrangements among lower-income households than among the highest income customers. Lower-income and smaller users, however, do appear to pay less for their solar PV systems, suggesting that sellers are able to capture some share of the rents that wealthier and high-consumption households get from installing PV. 
As a result of the retail rate structure and economies of scale in installing PV, and despite the influence of income and usage on the purchase price, the net present value of installing solar PV was higher for higher-income households for most of the sample period. I show, however, that this differential would have been absent under a flat rate structure.

It is important to note the limits of the data used here. Much of the analysis focused only on households that received subsidies under the CSI program. As a result, much of the analysis is limited for 2013 and beyond. Since then, the cost of solar PV panels has dropped significantly and prices for installed residential solar PV have also declined substantially. The economics of PV are improving, both at residential and grid-scale. With current incentives for residential PV, including the benefits of accelerated depreciation on third-party systems - which are now over two-thirds of new residential installations - the private net benefits appear to be positive for a far larger set of customers than even at the end of the sample studied here.

Still, the net present value calculations also support the view that distributed solar PV remains a fairly expensive source of electricity generation. With the end of the CSI, the three major sources of financial incentives are the $30 \%$ federal tax credit, the increasingblock pricing tariff that increases incentives for the largest customers (while decreasing it for small users), and, for third-party owned systems, the value of accelerated depreciation.

The tax credit is scheduled to decrease to $10 \%$ for businesses and to $0 \%$ for individuals at the end of 2016. The steepness of increasing-block pricing in California has already decreased with the highest tier now about double the lowest, rather than about triple as it averaged from 2007 to early 2014. And proposed changes now under consideration by the California Public Utilities Commission compress the tiers further. Accelerated depreciation is also under political pressure. If these incentives were lost, even with the recent declines in residential PV prices it seems unlikely that DG solar would remain privately economic.

Numerous countries and U.S. states are now promoting residential solar PV with direct subsidies, renewable energy credits, tax breaks and other incentives. This analysis demonstrates that residential electricity rate design can also play a primary role in creating incentives for residential solar adoption and in how those incentives are distributed across households of different incomes. 


\section{REFERENCES}

Auerbach, Alan J. 1982. "The New Economics of Accelerated Depreciation." Boston College Law Review, September, 1327-55.

Baker, Erin, Meredith Fowlie, Derek Lemoine, and Stanley S. Reynolds. 2013. "The Economics of Solar Electricity." Annual Review of Resource Economics, 5: 387-426.

Barbose, Galen L., Samantha Weaver, and Naïm Darghouth. 2014. "Tracking the Sun VII: An Historical Summary of the Installed Price of Photovoltaics in the United States from 1998 to 2013." Berkeley: Lawrence Berkeley National Laboratory. September. Working Paper LBNL-6350E.

Borenstein, Severin. 2008a. "The market value and cost of solar photovoltaic electricity production." Center for the Study of Energy Markets Working Paper 176. http://www.ucei.berkeley.edu/PDF/csemwp176.pdf.

Borenstein, Severin. 2008b. "Response to Critiques of "The market value and cost of solar photovoltaic electricity production'." http://faculty.haas.berkeley.edu/borenste/PVwork.html

Borenstein, Severin. 2012a. "The Private and Public Economics of Renewable Electricity Generation," Journal of Economic Perspectives, 26(1), Winter 2012.

Borenstein, Severin. 2012b. "The Redistributional Impact of Non-Linear Electricity Pricing." American Economic Journal: Economic Policy, 4(3): 56-90.

Buller, Susan M. 2013. "Comparison of CPUC Income Analysis and PG\&E Income Analysis." Pacific Gas \& Electric, mimeo.

California Public Utilities Commission. 2012. "California Solar Initiative Annual Program Assessment, June 2012." Available at

http://www.cpuc.ca.gov/PUC/energy/Solar/2012CASolarLegReport.htm

California Public Utilities Commission. 2013. "California Net Energy Metering Ratepayer Impacts Evaluation, October 2013." Available at http://www.cpuc.ca.gov/NR/rdonlyres/D74C5457-B6D9-40F4-8584-60D4AB756211/0/NEMReportwithAppendices.pdf

Darghouth, Naïm, Galen L. Barbose, and Ryan H. Wiser. 2011. "The impact of rate design and net metering on the bill savings from distributed PV for residential customers in California." Energy Policy. 39. 5243-5253.

Darghouth, Nä̈m, Galen L. Barbose, and Ryan H. Wiser. 2013. "Electricity Bill Savings from Residential Photovoltaic Systems: Sensitivities to Changes in Future Electricity Market Conditions." Berkeley: Lawrence Berkeley National Laboratory, 2013. Working Paper LBNL-6017E.

Dong, C.G., Ryan Wiser and Varun Rai. 2014. "Incentive Pass-through for Residential Solar Systems in California." Berkeley: Lawrence Berkeley National Laboratory, October. Working Paper LBNL-6927E. 
Energy \& Environmental Economics. 2013. California Net Energy Metering Ratepayer Impacts Evaluation, report prepared for the California Public Utilities Commission. October.

Gillingham, Kenneth, Hao Deng, Ryan Wiser, Nä̈m Darghouth, Gregory Nemet, Galen Barbose, Varun Rai, and C.G. Dong. 2014. "Deconstructing Solar Photovoltaic Pricing: The Role of Market Structure, Technology and Policy," Lawrence Berkeley National Lab Working Paper. December.

Henwood, Keith. 2014. "Subsidy Pass-through is Residential Solar Markets," University of Chicago working paper, October.

Hughes, Jonathan E. and Molly Podolefsky. 2013. "Getting Green with Solar Subsidies: Evidence from the California Solar Initiative," University of Colorado Working Paper. October.

Ito, Koichiro. 2014. "Do Consumers Respond to Marginal or Average Price? Evidence from Nonlinear Electricity Pricing." American Economic Review. 104(2): 537-563.

Maguire, Kelly and Glenn Sheriff. 2011. "Comparing Distributions of Environmental Outcomes for Regulatory Environmental Justice Analysis." International Journal of Environmental Research and Public Health. 8:1707-1726.

Podolefsky, Molly. 2013. "Tax Evasion and Subsidy Pass-Through under the Solar Investment Tax Credit," University of Colorado Working Paper 13-05. November. 


\section{Appendix A: Calculating the benefit of accelerated depreciation}

Consider an individual homeowner who buys and owns a solar PV system. She does not pay taxes on the output of the system and she is not allowed to take a tax deduction for depreciation of the system. Now consider a company that owns the system. The income it earns leasing out the system or selling energy under a PPA is taxable and the company can claim a tax deduction for depreciation of the system. In the simplest setting, if the operating profit (before capital depreciation) just matched true economic depreciation of the system, and if the depreciation that could be claimed as a tax deduction also matched the economic depreciation, then the firm would have no tax liability or benefit from the taxation in any year. In fact, so long as the NPV of the tax deduction for depreciation is equal to the NPV of the true economic depreciation, then the firm would face a only a non-distorting tax on its true economic profit. ${ }^{44}$

If, however, the NPV of the tax deduction for depreciation that the firm is allowed to take is greater than the NPV of the economic depreciation - which could occur if the tax deduction is accelerated relative to economic depreciation or is just set higher than the economic depreciation - then a business owner that faces such taxes and deductions gets a net benefit compared to a homeowner that faces no taxation. In the very simplest case, if the NPV of the true economic profit were zero, ${ }^{45}$ but the company could deduct the entire cost of the system in the year it is purchased, yet only pay taxes on the operating profit over the years as the net revenue rolls in, then the firm would be much better off than if it paid no taxes at all, as the homeowner does.

In the empirical analysis, I do not compare the accelerated depreciation to deduction of true economic depreciation, because that is not the treatment of other generation sources. Standard accounting depreciates long-lived assets such as generation facilities over 20 years. Thus, I compare the net present value of the tax deduction received under standard treatment to the net present value of the deduction under accelerated depreciation. I assume that depreciation is calculated based on the double declining balance method with the firm facing a nominal interest rate of $7 \%$ and an inflation rate of $3 \%$ annually. I assume that the firm is in a $35 \%$ marginal tax rate, which is the corporate tax rate for firms of significant size.

As a baseline, I compare to depreciation of the asset over 20 years with depreciation

\footnotetext{
44 This assumes that the marginal tax rate faced by the firm doesn't change over time.

45 Meaning that, untaxed, the NPV of revenues the firm earns from the system exactly equals the NPV of its costs.
} 
permitted only for the owner's net cost after receiving the CSI rebate and the $30 \%$ federal tax credit. ${ }^{46}$ The actual depreciation allowed differs from this baseline for three reasons: (1) Firms were allowed to depreciate $85 \%$ of the system cost (after state rebates), not the $70 \%$ they actually had to pay after they took the federal tax credit; (2) for the entire sample period, firms were allowed to depreciate the system over 5 years rather than 20 ; and, (3) from 2008 to 2013 firms were allowed to take a larger share of the depreciation in the first year, known as a bonus depreciation, $50 \%$ for the entire period except September 8, 2010 to December 31, 2011 when the bonus was 100\%, that is, the entire system was expensed in the first year.

In a spreadsheet, I calculated the NPV of the tax savings from depreciation of the system under standard 20-year depreciation of the system cost, which would be $70 \%$ of the cost after state incentives. I then recalculate the NPV with the additional factors listed in the previous paragraph. As a percentage of the full cost of the system, after state incentives, I calculated that depreciation under normal 20-year treatment would results in a NPV tax savings of $\$ 4,472$ on a $\$ 30,000$ system (after state rebate). With deductability of $85 \%$ rather than $70 \%$, the NPV of tax savings rises to $\$ 5,431$, an addition savings of $\$ 959$ or $3.8 \%$ of the net cost under normal depreciation (of $\$ 25,528$ ). With accelerated depreciation (to 5 years), this additional savings rises to $12.6 \%$. Under accelerated depreciation with a $50 \%$ first-year bonus, it's $13.9 \%$. And with $100 \%$ depreciation in the first year, it is $15.2 \%$. In calculating the incentives, I use these percentages as a function of the net cost after state incentives and the federal tax credit.

46 The CSI rebate actually received by the system is used in the calculation. All company-owned systems were eligible for the $30 \%$ federal tax credit during the sample period. 